\title{
MINUMAN TINGGI AKTIVITAS ANTIOKSIDAN BERBAHAN DASAR ALAMI MINYAK BEKATUL PADI (Oryzae sativa) DAN EKSTRAK MENIRAN (Phyllanthus niruri)
}

\section{(High Antioxidant Activity of Beverages Based on Natural Rice Bran Oil [Oryzae sativa] and Meniran Extract [Phyllanthus niruri])}

\author{
Purnawati Hustina Rachman ${ }^{1}$, Priskila ${ }^{1}$, Evy Damayanthi ${ }^{1^{*}}$, dan Bambang Pontjo Priosoeryanto ${ }^{2}$ \\ ${ }^{1}$ Departemen Gizi Masyarakat, Fakultas Ekologi Manusia (FEMA), Institut Pertanian Bogor, \\ Jl. Raya Darmaga, Bogor 16880 \\ 2Departemen Patologi, Fakultas Kedokteran Hewan (FKH), Institut Pertanian Bogor, \\ Jl. Raya Darmaga, Bogor 16880
}

\begin{abstract}
This study aimed to assess the antioxidant potential of chocholate-rice bran oil-emulsion beverage and meniran extract beverage. RBO beverage was made using oil in water emulsion with sugar ester as the emulsifier. Four formulas was created with the RBO-chocolate concentrate : water ratio of 1:1, 1:3, 1:5, and 1:7. Meanwhile the meniran beverage was made by adding extract meniran in five different concentrations $(30,40,50,60,70 \mathrm{ppm})$ along with flavor and sucralose. The selected emulsion beverage had the AEAC value of $30.75 \mathrm{mg}$ Vit C/100 g, while the meniran extract beverage had the AEAC value of $9.12 \mathrm{mg} \mathrm{Vit} \mathrm{C/100 \textrm {g }}$ with the total fenol of $92.75 \mathrm{mg} / 100 \mathrm{~g}$. The results of TBA value, content of protein, fat, carbohydrate, ash, and water of the emulsion beverage were $0.12 \mathrm{mg}$ malondialdehyde eq $/ \mathrm{kg}, 0.24 \%, 0.52 \%, 6.74 \%, 0.15 \%$ and 92.32\%, respectively. Increasing concentrations of chocolate and RBO significantly affected the results of the chemical parameters $(p<0.05)$. Overall, the chocolate emulsion beverage based on RBO and meniran extract beverage had high antioxidant activity that are potential to prevent non-communicable diseases.
\end{abstract}

Keywords: antioxidants, chocolate, emulsion beverage, meniran, rice bran oil

\begin{abstract}
ABSTRAK
Penelitian ini bertujuan untuk mengkaji potensi aktivitas antioksidan dalam pembuatan minuman emulsi minyak bekatul-cokelat dan minuman ekstrak meniran. Minuman minyak bekatul dibuat menggunakan emulsi minyak dalam air dan sugar ester sebagai emulsifier. Dibuat empat formula minuman dengan perbandingan minyak bekatul-cokelat:air yaitu 1:1, 1:3, 1:5, 1:7. Sedangkan minuman meniran dibuat dengan menambahkan ekstrak meniran pada lima konsentrasi yang berbeda $(30,40,50,60,70 \mathrm{ppm})$ serta ditambahkan flavor dan gula. Minuman Emulsi yang terpilih mempunyai nilai AEAC $30.75 \mathrm{mg}$ Vit C/100 g, sedangkan minuman ekstrak meniran $9.12 \mathrm{mg}$ Vit C/100 g dengan total fenol $92.75 \mathrm{mg} / 100 \mathrm{~g}$. Hasil bilangan TBA, kandungan protein, lemak, karbohidrat, abu, dan air dari minuman emulsi masing-masing $0.12 \mathrm{mg}$ malondialdehid eq $/ \mathrm{kg}, 0.24 \%, 0.52 \%$, $6.74 \%, 0,15 \%$ dan $92.32 \%$. Meningkatnya konsentrasi cokelat dan minyak bekatul secara nyata memengaruhi hasil dari parameter kimia $(p<0.05)$. Secara keseluruhan, minuman emulsi minyak bekatul-cokelat dan minuman ekstrak meniran memiliki aktivitas antioksidan tinggi yang berpotensi untuk mencegah penyakit tidak menular.
\end{abstract}

Kata kunci: antioksidan, cokelat, meniran, minuman emulsi, minyak bekatul

"Korespondensi: Departemen Gizi Masyarakat, Fakultas Ekologi Manusia (FEMA), Institut Pertanian Bogor, Jl. Raya Darmaga, Bogor 16880; Email: evyimam@yahoo.com 
Rachman dkk.

\section{PENDAHULUAN}

Dewasa ini, kecenderungan pola penyebaran penyakit telah mengalami perubahan yang diikuti dengan perubahan demografi. Hasil Laporan Riset Kesehatan Dasar (Riskesdas) tahun 2007 (Depkes 2008) memperlihatkan bahwa selama 12 tahun (1995-2007) proporsi kematian karena penyakit tidak menular, terutama penyakit degeneratif semakin meningkat seperti penyakit jantung koroner, kanker, dan diabetes melitus. Salah satu solusi untuk mengatasi permasalahan tersebut adalah dengan mengonsumsi pangan fungsional.

Akhir-akhir ini penelitian terkait dengan pengaruh pangan antioksidan dan pangan fungsional lainnya pada kesehatan banyak dilakukan. Lee et al. (2011) melaporkan bahwa suplementasi jus wortel dan B-karoten pada perokok memiliki potensi antioksidasi yang besar guna mencegah kerusakan DNA limfosit pada subyek perokok. Para perokok membutuhkan antioksidan untuk menetralkan radikal bebas yang terbentuk selama merokok. Kerusakan oksidasi yang berlanjut akan mengakibatkan kerusakan DNA sehingga meningkatkan penyakit tidak menular seperti penuaan dan kanker (Ames et al. 1993). Damayanthi et al. (2011) pemberian jus tomat dan minuman bekatul padi pada wanita dewasa yang memiliki lesi kista ternyata dapat mengecilkan ukuran lesi kista. Damayanthi et al. (2009) melaporkan bahwa pemberian seduhan teh hijau dan teh daun murbey dapat memperbaiki kadar glukosa darah tikus diabet yang diinduksi oleh aloksan. Dua komoditas lokal alami yang tinggi antioksidan dan menjadi fokus penelitian ini adalah minyak bekatul padi dan meniran (Phylanthus niruri).

Minyak bekatul padi (rice bran oil) merupakan salah satu komoditas yang sangat melimpah di Indonesia dan dilaporkan kaya akan kandungan senyawa antioksidan sehingga berpotensi diolah menjadi pangan fungsional. Studi membuktikan bahwa bekatul mampu menghambat pertumbuhan tumor atau kanker, hiperkolesterolemia, kanker kolon, dan aterosklerosis (Damayanthi et al. 2003; Damayanthi et al. 2004). Namun saat ini pemanfaatan minyak bekatul di Indonesia masih sangat jarang dilakukan, sehingga perlu upaya untuk meningkatkan penggunaan minyak bekatul dalam produk pangan. Teknik pemanfaatan minyak dalam pengembangan produk makanan adalah dengan menggunakan teknik emulsi. Pada penelitian ini dikembangkan minuman emulsi minyak bekatul-cokelat. Penambahan cokelat pada minuman emulsi selain untuk meningkatkan cita rasa minuman, juga untuk meningkatkan kandungan antioksidan di dalamnya.

Sementara itu meniran merupakan tanaman herbal yang mengandung lignan, flavonoid, alkaloid, triterpenoid, asam lemak, kalium, damar, dan tanin. Hasil penelitian Gunawan et al. (2008) menunjuk- kan bahwa meniran mempunyai efek hipoglikemik, diuretik, antihepatotoksik, analgesik, antitumor/ antikanker/antineoplasia. Ekstrak meniran diketahui berpotensi sebagai imunostimulan. Senyawa flavonoid yang terkandung dalam meniran berkhasiat sebagai antioksidan dan antitumor (Mangan 2005).

Tujuan penelitian ini adalah mengkaji potensi aktivitas antioksidan, dan mengetahui cara pembuatan, sifat organoleptik, serta sifat kimia (proksimat, aktivitas antioksidan, total fenol, dan bilangan tiobarbituric acid) minuman emulsi minyak bekatulcokelat dan minuman ekstrak meniran.

\section{METODE}

\section{Desain, Tempat, dan Waktu}

Desain penelitian ini adalah experimental study. Lokasi penelitian dilakukan di empat laboratorium yang meliputi Laboratorium Percobaan Makanan, Laboratorium Analisis Zat Gizi, Laboratorium Organoleptik, dan Laboratorium Biokimia Gizi Departemen Gizi Masyarakat, Fakultas Ekologi Manusia, Institut Pertanian Bogor. Penelitian ini dilaksanakan mulai bulan Maret sampai November 2011.

\section{Bahan dan Alat}

Bahan-bahan yang digunakan dalam pengembangan produk minuman emulsi minyak bekatulcokelat adalah Rice Bran Oil (merek Oryza Grace), cokelat bubuk dengan $100 \%$ kandungan kakao yang diperoleh dari Balai Penelitian Tanaman Kopi dan Kakao Jember, sukralosa, emulsifier sugar ester, CMC, dan garam. Bahan percobaan yang digunakan untuk pembuatan minuman herbal dalam penelitian ini adalah berupa serbuk ekstrak meniran, sukralosa, garam, flavor, dan air matang. Bahan kimia yang digunakan untuk analisis proksimat, aktivitas antioksidan, total fenol dan TBA adalah etanol teknis $95 \%, \mathrm{HCl} 0.001 \mathrm{~N} \& 0.02 \mathrm{~N}, \mathrm{~K}_{2} \mathrm{SO}_{4}, \mathrm{HgO}, \mathrm{H}_{2} \mathrm{SO}_{4}$, $\mathrm{H}_{3} \mathrm{BO}_{3}$, indikator merah metil dan metil biru, $\mathrm{NaOH}$ $\mathrm{Na}_{2} \mathrm{~S}_{2} \mathrm{O}_{3}$, aseton $70 \%$, buffer asetat, DPPH, metanol, asam askorbat, pereaksi Folin-Ciocateau, $\mathrm{Na}_{2} \mathrm{CO}_{3}$ 20\%, larutan asam galat, dan TBA.

Peralatan yang digunakan dalam pembuatan minuman emulsi adalah homogenizer, panci, baskom, timbangan, termometer, dan kompor gas. Alat-alat untuk analisis kimiawi adalah alat titrasi, penangas air, batu didih, timbangan analitik, sudip, tabung reaksi, pipet volumetrik $10 \mathrm{ml}$, erlenmeyer, pipet mohr, pipet tetes, gelas piala, cawan alumunium, evaporator, alumunium foil, rotavor, vortex, oven, spektrofotometer, desikator, tanur, freeze dryer, sentrifuse, dan neraca digital.

\section{Tahapan Penelitian}

Penelitian ini terdiri dari dua tahapan. Tahap pertama adalah studi mengenai potensi aktivitas antioksidan minuman emulsi minyak bekatul-cokelat 
dan tahap kedua adalah mengenai potensi aktivitas antioksidan minuman ekstrak meniran. Jenis analisis yang dilakukan pada minuman emulsi minyak bekatul-cokelat yaitu uji organoleptik, proksimat, bilangan TBA dan aktivitas antioksidan dengan DPPH. Sedangkan untuk minuman ekstrak meniran yang akan di analisis yaitu uji organoleptik, aktivitas antioksidan dengan DPPH dan total fenol.

\section{Pembuatan minuman emulsi minyak bekatul- cokelat}

Tahapan pembuatan minuman emulsi yang pertama adalah pembuatan larutan biang melalui pencampuran bahan kering (emulsifier, cokelat bubuk, dan CMC) dengan bahan basah (minyak bekatul dan air). Selanjutnya dilakukan proses homogenisasi terhadap hasil pencampuran tersebut menggunakan homogenizer dengan kecepatan 11000 rpm selama 10 menit. Setelah diperoleh larutan biang, kemudian dilakukan pengenceran dengan perbandingan larutan biang:air antara lain 1:1, 1:3, 1:5, dan 1:7. Selanjutnya ditambahkan sukralosa dan garam pada minuman emulsi dan di homogenisasi kembali menggunakan homogenizer dengan kecepatan $9000 \mathrm{rpm}$ selama 30 detik. Selanjutnya di pasteurisasi dengan suhu $60^{\circ} \mathrm{C}$ selama 30 menit. Minuman emulsi dibuat per takaran saji yaitu $200 \mathrm{ml}$.

\section{Pembuatan minuman ekstrak meniran}

Konsentrasi ekstrak meniran yang digunakan untuk formulasi minuman yaitu 30, 40,50, 60, dan $70 \mathrm{ppm}$. Flavor yang digunakan merupakan esens cair food grade beraroma pala agar memberikan warna cerah dan aroma yang kuat. Pemanis yang digunakan yaitu sukrosa dan sukralosa dengan tingkat kemanisan 15. Perbandingan tingkat kemanisan yang digunakan dalam formulasi antara sukrosa dan sukralosa yaitu 5:10. Pembuatan minuman diawali dengan melarutkan ekstrak meniran dalam 1 liter air hingga mencapai konsentrasi yang diharapkan. Masing-masing larutan ekstrak ditambahkan flavor sebanyak $0.1 \%$, pemanis $15 \%$, dan garam $0.1 \%$ dihitung berdasarkan bobot volume. Setelah dihomogenisasi, minuman dikemas untuk uji organoleptik.

\section{Uji organoleptik}

Pada penelitian ini uji organoleptik dilakukan oleh 30 orang panelis semi terlatih untuk menentukan satu formula terpilih dari empat formula minuman emulsi minyak bekatul-cokelat bubuk dan untuk menentukan daya terima panelis terhadap produk minuman ekstrak meniran.

\section{Analisis kimia}

Sifat kimia yang dianalisis antara lain proksimat (kadar air dengan metode oven (Apriyantono et al. 1989), kadar abudengan tanur (Apriyantono et al. 1989), kadar protein dengan metode kjeldahl mikro (Apriyantono et al. 1989), kadar lemak dengan metode soxhlet, kadar karbohidrat menggunakan carbohydrate by difference, aktivitas antioksidan dengan metode DPPH (Kubo et al. 2002), Bilangan TBA (Tarladgis 1960) dan total fenol (Javanmardi et al. 2003).

\section{Pengolahan dan Analisis Data}

Rancangan yang digunakan pada tahap pertama adalah Rancangan Acak Lengkap (RAL) dengan 2 taraf yaitu konsentrasi minyak bekatul dan cokelat bubuk pada formula 1:1 dan formula 1:3. Tahap kedua menggunakan Rancangan Acak Lengkap (RAL) dengan menghitung respon panelis terhadap taraf konsentrasi ekstrak meniran dalam minuman. Analisis kimia dilakukan dengan dua kali ulangan dan dianalisis menggunakan uji sidik ragam (ANOVA). Apabila berpengaruh secara nyata $(p<0.05)$ maka dilanjutkan dengan uji lanjut Duncan.

\section{HASIL DAN PEMBAHASAN}

Pada penelitian tahap pertama dibuat empat formulasi minuman emulsi minyak bekatul-cokelat (Tabel 1). Konsentrasi cokelat dan minyak bekatul dalam minuman dilakukan dengan pengenceran terhadap larutan biang dengan perbandingan larutan biang banding air 1:7, 1:5, 1:3, dan 1:1. Pengenceran dilakukan akibat after taste yang ditimbulkan minuman sehingga diperlukan upaya untuk mengurangi rasa yang kurang disukai tersebut. Pada pe-

Tabel 1. Komposisi Minuman Emulsi Minyak Bekatul-Cokelat Bubuk

\begin{tabular}{llcccccc}
\hline \multirow{2}{*}{ No Bahan } & \multicolumn{1}{c}{ Komposisi Biang } & \multicolumn{5}{c}{ Komposisi Minuman Emulsi (\%) } \\
\cline { 2 - 7 } & & $\%$ & $1: 7$ & $1: 5$ & $1: 3$ & $1: 1$ & Kontrol \\
\hline 1 & Air & 69.57 & 96.11 & 94.83 & 92.27 & 84.581 & 93.508 \\
2 & Cokelat & 4.97 & 0.63 & 0.84 & 1.26 & 2.515 & 0.000 \\
3 & RBO & 24.85 & 3.14 & 4.19 & 6.29 & 12.577 & 6.288 \\
4 & Emulsifier & 0.50 & 0.06 & 0.08 & 0.13 & 0.252 & 0.126 \\
5 & Garam & 0.05 & 0.05 & 0.05 & 0.05 & 0.050 & 0.050 \\
6 & CMC & 0.050 & 0.006 & 0.008 & 0.013 & 0.025 & 0.013 \\
7 & Sucralose & 0.015 & 0.015 & 0.015 & 0.015 & 0.015 & 0.015 \\
\hline
\end{tabular}


Tabel 2. Komposisi Bahan Minuman Herbal Ekstrak Meniran per Liter

\begin{tabular}{llccccc}
\hline \multirow{2}{*}{ No } & Bahan & \multicolumn{5}{c}{ Konsentrasi Meniran (ppm) } \\
\cline { 3 - 7 } & (per liter minuman) (g) & 30 & 40 & 50 & 60 & 70 \\
\hline 1 & Ekstrak Meniran & 0.03 & 0.04 & 0.05 & 0.06 & 0.07 \\
2 & Sukralose & 0.07 & 0.07 & 0.07 & 0.07 & 0.07 \\
3 & Gula Pasir & 24.34 & 24.34 & 24.34 & 24.34 & 24.34 \\
4 & Garam & 0.97 & 0.97 & 0.97 & 0.97 & 0.97 \\
5 & Flavor & 0.49 & 0.49 & 0.49 & 0.49 & 0.49 \\
6 & Air & 973.61 & 973.60 & 973.59 & 973.58 & 973.57 \\
\hline
\end{tabular}

Tabel 3. Pengaruh Konsentrasi Minyak Bekatul dan Cokelat pada Minuman Emulsi terhadap Uji Mutu Hedonik

\begin{tabular}{cccccc}
\hline Formula & Warna & Kekentalan & Aroma & Rasa & After taste \\
\hline $1: 1$ & $3.56 \mathrm{a}$ & $5.56 \mathrm{a}$ & $6.66 \mathrm{a}$ & $3.96 \mathrm{a}$ & $3.96 \mathrm{a}$ \\
$1: 3$ & $4.45 \mathrm{~b}$ & $6.81 \mathrm{~b}$ & $6.44 \mathrm{a}$ & $5.11 \mathrm{~b}$ & $5.11 \mathrm{~b}$ \\
$1: 5$ & $5.09 \mathrm{c}$ & $7.45 \mathrm{bc}$ & $6.20 \mathrm{a}$ & $5.41 \mathrm{~b}$ & $5.41 \mathrm{~b}$ \\
$1: 7$ & $5.76 \mathrm{~d}$ & $7.59 \mathrm{c}$ & $6.18 \mathrm{a}$ & $5.51 \mathrm{~b}$ & $5.51 \mathrm{~b}$ \\
\hline \multicolumn{7}{l}{ Keterangan: perbedaan huruf/angka pada baris yang sama menyatakan nilai yang } \\
berbeda nyata & & &
\end{tabular}

nelitian tahap kedua formulasi minuman fungsional yang diberi ekstrak meniran dilakukan dengan lima taraf konsentrasi ekstrak yaitu 30-70 ppm. Komposisi bahan per liter minuman yang digunakan pada setiap formulasi disajikan dalam Tabel 2 .

\section{Uji Organoleptik}

Uji organoleptik kedua produk yang dilakukan terdiri dari uji mutu hedonik dan uji hedonik atau kesukaan. Pada uji mutu hedonik minuman emulsi minyak bekatul-cokelat panelis diminta mengungkapkan tanggapan pribadinya mengenai mutu atau kualitas minuman emulsi minyak bekatul dengan berbagai formulasi yaitu formula 1:1, formula 1:3, formula 1:5, dan formula 1:7. Rentang skala yang digunakan adalah 1 sampai 9 untuk parameter warna, kekentalan, aroma, rasa, dan after taste. Pengaruh perlakuan terhadap uji mutu hedonik terdapat pada Tabel 3.

Berdasarkan hasil uji organoleptik diketahui bahwa rata-rata penilaian uji mutu hedonik warna minuman emulsi berkisar antara cokelat tua-kuning kecokelatan. Rata-rata penilaian kekentalan berkisar antara kental lembut-agak kental agak lembut. Rata-rata penilaian aroma berkisar antara agak harum-harum. Rata-rata penilaian rasa berkisar antara agak pahit-agak manis. Rata-rata penilaian after taste berkisar antara agak sepat agak getiragak berminyak. Analisis sidik ragam menunjukkan bahwa konsentrasi minyak bekatul dan cokelat berpengaruh nyata terhadap parameter warna, kekentalan, rasa, dan after taste $(\mathrm{p}<0.05)$, namun tidak berpengaruh nyata terhadap aroma $(p>0.05)$.

Pada uji hedonik, rentang skala yang digunakan adalah 1 sampai 9 dengan skala terendah yaitu amat sangat tidak suka, dan yang tertinggi adalah amat sangat suka (Tabel 4). Berdasarkan hasil uji organoleptik diketahui bahwa rata-rata penilaian uji hedonik terhadap warna berkisar antara agak tidak suka sampai suka. Warna formula yang paling disukai panelis adalah formula 1:3. Rata-rata penilaian hedonik terhadap kekentalan berkisar antara agak tidak suka-agak suka. Kekentalan minuman yang paling disukai panelis adalah formula 1:1. Rata-rata penilaian hedonik terhadap aroma berkisar antara biasa-agak suka. Aroma minuman yang paling disukai panelis adalah formula 1:1. Rata-rata penilaian hedonik terhadap rasa berkisar antara agak tidak suka-agak suka. Rasa minuman yang paling disukai panelis adalah formula 1:5. Rata-rata penilaian hedonik terhadap after taste berkisar antara agak tidak suka-biasa. After taste minuman yang paling disukai panelis adalah formula 1:3. Analisis sidik ragam menunjukkan bahwa konsentrasi minyak bekatul dan cokelat berpengaruh nyata terhadap semua parameter $(\mathrm{p}<0.05)$.

Formula terbaik kemudian dipilih melalui proses rata-rata pembobotan kelima parameter uji hedonik. Skor bobot yang diberikan kepada masingmasing parameter didasarkan atas justifikasi peneliti dengan bobot sebagai berikut: warna 0.133 ; kekentalan 0.133; aroma 0.133; rasa 0.3; dan after taste 0.3 . Secara keseluruhan, panelis memberikan skor tertinggi pada minuman emulsi formula 1:3 dengan skor 5.666 yang menandakan panelis agak menyukai minuman tersebut. Selanjutnya kemudian diikuti dengan formula $1: 5$, formula $1: 1$, dan terakhir formula 1:7. Berdasarkan skor uji hedonik keseluruhan maka diperoleh formula terbaik adalah formula $1: 3$, sehingga formula tersebut dilakukan 
Tabel 4. Pengaruh Konsentrasi Minyak Bekatul dan Cokelat pada Minuman Emulsi Terhadap Uji Hedonik

\begin{tabular}{ccccccc}
\hline Formula & Warna & Kekentalan & Aroma & Rasa & After taste & Keseluruhan $^{* *}$ \\
\hline $1: 1$ & $6.329 \mathrm{~d}$ & $6.363 \mathrm{c}$ & $6.480 \mathrm{c}$ & $4.680 \mathrm{a}$ & $4.134 \mathrm{a}$ & 5.292 \\
$1: 3$ & $7.066 \mathrm{c}$ & $5.486 \mathrm{~b}$ & $5.920 \mathrm{bc}$ & $5.700 \mathrm{~b}$ & $5.325 \mathrm{~b}$ & 5.666 \\
$1: 5$ & $5.394 \mathrm{~d}$ & $4.603 \mathrm{a}$ & $5.637 \mathrm{ab}$ & $5.769 \mathrm{~b}$ & $5.051 \mathrm{~b}$ & 5.325 \\
$1: 7$ & $4.234 \mathrm{a}$ & $4.400 \mathrm{a}$ & $5.206 \mathrm{a}$ & $5.274 \mathrm{ab}$ & $5.006 \mathrm{~b}$ & 4.925 \\
\hline
\end{tabular}

*) Keterangan: perbedaan huruf/angka pada baris yang sama menyatakan nilai yang berbeda nyata

**) Diperoleh dari proses pembobotan kelima parameter uji hedonik

Tabel 5. Pengaruh Penambahan Ekstrak Meniran terhadap Mutu Hedonik dan Tingkat Kesukaan (Hedonik) Minuman

\begin{tabular}{ccccccccc}
\hline \multirow{2}{*}{ No } & \multirow{2}{*}{ Formula } & \multicolumn{3}{c}{ Uji Mutu Hedonik Minuman* } & \multicolumn{3}{c}{ Uji Hedonik Minuman ${ }^{* *}$} \\
\cline { 3 - 8 } & & Aroma & Kemanisan & Getir & Rasa segar & Warna & Aroma & Rasa \\
\hline 1 & $30 \mathrm{ppm}$ & $5.60 \mathrm{a}$ & $6.07 \mathrm{a}$ & $7.15 \mathrm{a}$ & $5.80 \mathrm{a}$ & $6.58 \mathrm{a}$ & $5.73 \mathrm{a}$ & $6.01 \mathrm{a}$ \\
2 & $40 \mathrm{ppm}$ & $5.65 \mathrm{a}$ & $6.44 \mathrm{a}$ & $7.41 \mathrm{a}$ & $5.80 \mathrm{a}$ & $6.63 \mathrm{a}$ & $5.81 \mathrm{a}$ & $5.80 \mathrm{a}$ \\
3 & $50 \mathrm{ppm}$ & $5.94 \mathrm{a}$ & $6.37 \mathrm{a}$ & $7.11 \mathrm{a}$ & $5.92 \mathrm{a}$ & $6.58 \mathrm{a}$ & $5.94 \mathrm{a}$ & $5.89 \mathrm{a}$ \\
4 & $60 \mathrm{ppm}$ & $5.87 \mathrm{a}$ & $6.40 \mathrm{a}$ & $7.23 \mathrm{a}$ & $5.74 \mathrm{a}$ & $6.41 \mathrm{a}$ & $5.77 \mathrm{a}$ & $5.98 \mathrm{a}$ \\
5 & $70 \mathrm{ppm}$ & $5.78 \mathrm{a}$ & $6.33 \mathrm{a}$ & $6.99 \mathrm{a}$ & $5.82 \mathrm{a}$ & $6.12 \mathrm{a}$ & $5.53 \mathrm{a}$ & $5.87 \mathrm{a}$ \\
\hline
\end{tabular}

Keterangan:

*Mutu hedonik: Aroma 1=amat sangat meniran 9=amat sangat pala; Kemanisan

1=amat sangat pahit 9=amat sangat manis; After taste 1=amat sangat getir 9=tidak getir sama sekali; Kesan segar $1=$ amat sangat tidak segar $9=$ amat sangat segar.

${ }^{* *}$ Uji Hedonik : Angka 1=amat sangat tidak suka, 9=amat sangat suka

***Nilai rata-rata pada kolom yang sama diikuti huruf sama menunjukan nilai yang tidak berbeda nyata (uji Duncan $a=0.05$ )

analisis lanjutan. Analisis lanjutan juga dilakukan pada formula 1:1 untuk melihat pengaruh peningkatan konsentrasi minyak bekatul dan cokelat bubuk terhadap aktivitas antioksidan, bilangan TBA dan uji proksimat.

Uji organoleptik tahap kedua pada minuman ekstrak meniran dilakukan untuk melihat daya terima panelis terhadap peningkatan konsentrasi ekstrak meniran yaitu 30, 40, 50, 60, dan 70 ppm. Parameter uji mutu hedonik antara lain aroma, kemanisan, getir, dan rasa segar. Nilai rata-rata hasil uji mutu hedonik dan hedonik minuman ekstrak meniran dapat dilihat pada Tabel 5 .

Berdasarkan hasil uji organoleptik diketahui bahwa rata-rata penilaian uji mutu hedonik aroma minuman ekstrak meniran memiliki aroma agak langu. Rata-rata penilaian kemanisan dinilai panelis agak manis, untuk parameter after taste kurang getir, dan untuk parameter kesan segar adalah agak segar. Analisis sidik ragam menunjukkan bahwa penambahan ekstrak meniran tidak berpengaruh nyata terhadap penilaian panelis ( $p>0.05)$.

Daya terima panelis dilihat melalui uji hedonik minuman ekstrak meniran terhadap tiga parameter yaitu warna, aroma, dan rasa. Rata-rata penilaian panelis terhadap parameter warna adalah agak suka, dengan formula 40 ppm yang paling disukai (6.63). Penilaian terhadap aroma berkisar antara kategori biasa hingga agak suka, dengan formula 50 ppm yang paling disukai (5.94), dan penilaian terhadap rasa termasuk dalam kategori agak suka, dengan formula 30 ppm yang paling disukai (6.01).

\section{Aktivitas Antioksidan, Bilangan TBA dan Analisis Proksimat Minuman Emulsi Minyak Bekatul}

\section{Aktivitas antioksidan}

Pada minuman emulsi minyak bekatul dengan penambahan cokelat bubuk, dapat dilihat bahwa terjadi peningkatan kapasitas antioksidan seiring dengan peningkatan konsentrasi minyak dan cokelat dalam minuman. Formula minuman emulsi 1:3 memiliki nilai AEAC yang lebih tinggi dibandingkan formula kontrol yaitu berturut turut $30.75 \mathrm{mg}$ Vit $\mathrm{C} / 100 \mathrm{~g}$ dan $26.43 \mathrm{mg}$ Vit C/100 g.

Mengingat bahwa kedua formulasi memiliki konsentrasi minyak bekatul yang sama, maka peningkatan nilai AEAC diduga disebabkan karena kandungan antioksidan yang terdapat pada cokelat bubuk. Hasil analisis bahan baku terhadap cokelat bubuk menunjukkan nilai AEAC yang sangat tinggi yaitu sebesar $1017.635 \mathrm{mg}$ vit C/100 g. Walaupun hasil analisis ANOVA menunjukkan bahwa perlakuan berpengaruh signifikan terhadap aktivitas antioksidan $(\mathrm{p}<0.05)$, namun uji lanjut Duncan memperlihatkan bahwa tidak terdapat perbedaan yang nyata antara kontrol dengan formula $1: 3$, sedangkan antara kontrol dan formula 1:3 berbeda nyata 
Tabel 6. Aktivitas Antioksidan dan Bilangan TBA dan Analisis Proksimat Minuman Emulsi Minyak BekatulCokelat

\begin{tabular}{lccccc}
\hline \multirow{2}{*}{ Jenis Analisis } & \multicolumn{3}{c}{ Minuman Emulsi } & \multicolumn{2}{c}{ Bahan baku } \\
\cline { 2 - 5 } & Kontrol & Formula 1:3 & Formula 1:1 & Cokelat & Minyak bekatul \\
\hline Kapasitas AAO (\%) & 24.41 & 37.68 & 66.74 & 91.45 & 87.32 \\
AEAC (mg Vit C/100g) & $26.43 \mathrm{a}$ & $30.75 \mathrm{a}$ & $112.64 \mathrm{~b}$ & 1017.64 & 986.41 \\
Bilangan TBA(mg MA eq/kg sampel) & $0.039 \mathrm{a}$ & $0.120 \mathrm{a}$ & $0.259 \mathrm{~b}$ & 0.655 & - \\
Analisis Proksimat: & & & & & - \\
-Kadar Protein (\%bb) & $0.11 \mathrm{a}$ & $0.24 \mathrm{~b}$ & $0.55 \mathrm{c}$ & - & - \\
-Kadar Lemak (\%bb) & $0.33 \mathrm{a}$ & $0.52 \mathrm{a}$ & $1.98 \mathrm{~b}$ & - & - \\
-Kadar Karbohidrat (\%bb) & $6.14 \mathrm{a}$ & $6.74 \mathrm{a}$ & $12.23 \mathrm{~b}$ & - & - \\
-Kadar Abu (\%bb) & $0.09 \mathrm{a}$ & $0.15 \mathrm{~b}$ & $0.20 \mathrm{c}$ & - & - \\
-Kadar Air (\%bb) & $93.20 \mathrm{a}$ & $92.32 \mathrm{~b}$ & $85.07 \mathrm{c}$ & - & \\
\hline
\end{tabular}

dengan formula 1:1. Hasil analisis aktivitas antioksidan minuman emulsi selengkapnya terdapat pada Tabel 6.

\section{Bilangan Tiobarbituric Acid (TBA)}

Tabel 6 menunjukkan bahwa bilangan TBA pada minuman emulsi dengan perlakuan formula 1:1 lebih tinggi secara nyata terhadap formula 1:3 dan kontrol $(p<0.05)$. Hal ini mungkin disebabkan kandungan minyak dari minyak bekatul dan cokelat yang lebih banyak pada formula 1:1 dibandingkan formula 1:3. Asam lemak akan mengalami reaksi oksidasi sehingga menghasilkan peroksida dan reaksi lanjutan berupa dekomposisi hidroperoksida menjadi senyawa aldehid dan keton. Bilangan TBA untuk formula kontrol, 1:3, dan 1:1 berturut-turut adalah $0.039,0.120$, dan $0.259 \mathrm{mg}$ MA eq $/ \mathrm{kg}$ sampel.

\section{Analisis proksimat}

Analisis proksimat pada minuman emulsi minyak bekatul-cokelat dilakukan untuk melihat komposisi gizi yang terkandung dalam minuman. Berdasarkan hasil analisis dapat diketahui bahwa semakin tinggi konsentrasi minyak bekatul dan cokelat bubuk dalam minuman emulsi maka semakin tinggi pula kadar protein, kadar lemak, dan kadar karbohidrat didalamnya, namun semakin rendah kadar air dan kadar abu (Tabel 6). Kadar protein tertinggi dimiliki oleh formula 1:1. Mengingat bahwa kandungan protein minyak bekatul 0 , diduga bahwa kadar protein yang terdapat pada minuman emulsi berasal dari cokelat bubuk. Diketahui pula bahwa kadar protein bahan baku cokelat bubuk yang digunakan adalah sebesar $19.36 \%$. Berdasarkan uji sidik ragam diketahui bahwa peningkatan konsentrasi minyak bekatul dan cokelat berpengaruh nyata terhadap kadar protein sampel $(p<0.05)$. Kadar lemak tertinggi dimiliki oleh formula 1:1. Hal ini diduga karena komposisi minyak bekatul dan cokelat bubuk pada formula tersebut lebih tinggi dibandingkan dengan formula yang lainnya. Analisis sidik ragam menunjukkan bahwa perlakuan berpengaruh nyata terhadap kadar lemak minuman $(p<0.05)$. Kadar karbohidrat tertinggi juga dimiliki oleh formula 1:1. Berdasarkan label pangan pada minyak komersil merek Oryza Rice Bran Oil, tertera bahwa terdapat $0 \mathrm{~g}$ karbohidrat pada minyak bekatul. Sehingga peningkatan kadar karbohidrat diduga karena konsentrasi cokelat bubuk yang meningkat serta bahan pengisi lainnya yang juga meningkat seiring dengan peningkatan konsentrasi minyak dan cokelat. Analisis sidik ragam menunjukkan bahwa perlakuan berpengaruh nyata terhadap kadar karbohidrat minuman $(\mathrm{p}<0.05)$.

Kadar abu tertinggi dimiliki oleh formula 1:1. Tingginya kadar abu pada suatu produk pangan mengindikasikan banyaknya zat anorganik atau mineral dalam bahan pangan tersebut. Analisis sidik ragam menunjukkan bahwa perlakuan berpengaruh nyata terhadap kadar abu minuman $(p<0.05)$. Kadar air tertinggi dimiliki oleh kontrol. Hal ini disebabkan karena komposisi air pada formula semakin menurun seiring dengan peningkatan konsentrasi minyak bekatul dan cokelat bubuk. Analisis sidik ragam menunjukkan bahwa perlakuan berpengaruh nyata terhadap kadar air minuman $(p<0.05)$.

\section{Sifat Kimiawi Ekstrak Air Meniran dan Total Fenol Minuman Herbal Ekstrak Meniran}

Pengujian sifat kimiawi serbuk ekstrak air meniran dilakukan untuk mengetahui kadar air, total fenol, dan aktivitas antioksidan. Tabel 7 menunjukkan hasil analisis sifat kimia ekstrak air meniran. Lebih dari 90\% komponen aktif ekstrak air meniran merupakan fenol. Dalam tubuh senyawa fenolik dapat berperan sebagai antioksidan yang menangkap radikal bebas (Cai et al. 2004). Aktivitas tersebut dikenal juga dengan aktivitas antioksidan.

Aktivitas antioksidan serbuk ekstrak meniran rata-rata mencapai $50 \%$, yang artinya, mampu mereduksi DPPH hingga 50\%. Kapasitas antioksidan dihitung sebagai kesetaraan dengan asam askorbat. 
Tabel 7. Sifat Kimiawi Ekstrak Air Meniran

\begin{tabular}{lc}
\hline \multicolumn{1}{c}{ Parameter } & Hasil Uji \\
\hline Kadar air & $14.5 \%$ \\
Total fenol & $92.75 \mathrm{mg} / 100 \mathrm{~g}$ \\
Aktivitas antioksidan & $50 \%(9.125 \mathrm{mg} / 100 \mathrm{~g} \mathrm{AEAC})$ \\
\hline
\end{tabular}

Tabel 8. Kandungan Fenol dalam Minuman Herbal Ekstrak Meniran

\begin{tabular}{cccc}
\hline $\begin{array}{c}\text { Konsentrasi Ekstrak } \\
(\mathrm{ppm})\end{array}$ & $\begin{array}{c}\text { Volume Minuman } \\
(\mathrm{ml})\end{array}$ & $\begin{array}{c}\text { Kandungan Fenol } \\
(\mathrm{mg})\end{array}$ & AEAC \\
\hline 30 & & 6.94 & 0.94 \\
40 & & 9.28 & 0.95 \\
50 & 200 & 9.8 & 1.05 \\
60 & & 11.7 & 1.24 \\
70 & & 12.9 & 1.31 \\
\hline
\end{tabular}

Meninjau kemampuannya dalam mereduksi radikal bebas, maka ekstrak meniran dikatakan potensial sebagai komponen antioksidan alami.

Mekanisme penangkapan radikal bebas pada ekstrak meniran terhadap DPPH dapat terjadi karena senyawa dalam ekstrak meniran menyumbangkan atom hidrogen yang kemudian ditangkap oleh DPPH. Senyawa aktif tersebut yaitu fenolik dan turunannya terutama flavonoid (Molyneux 2003). Flavonoid sendiri diketahui memiliki banyak bukti klinis terhadap pencegahan penyakit degeneratif, termasuk kemampuan antiproliferatif terhadap sel tumor.

Perhitungan total fenol juga dilakukan terhadap produk minuman herbal ektrak meniran. Kurva standar dibuat dengan menggunakan $\mathrm{mg}$ asam galat yang disetarakan dengan $\mathrm{mg}$ fenol pada sampel. Hasil perhitungan kandungan total fenol pada minuman herbal ekstrak meniran disajikan pada Tabel 8 . Peningkatan ekstrak meniran pada minuman diikuti dengan peningkatan total fenol pada tiap takaran saji minuman $(200 \mathrm{ml})$. Kandungan fenol tertinggi pada minuman diperoleh pada konsentrasi ekstrak 70 ppm dengan fenol sebesar 12.9 mg/200 $\mathrm{ml}$. Nilai tersebut rendah bila dibandingkan dengan kandungan fenol pada minuman lain seperti sari jeruk, kopi, dan teh. Pada $200 \mathrm{ml}$ air jeruk terdapat $150 \mathrm{mg}$ fenol, sedangkan pada $200 \mathrm{ml}$ teh dan kopi berturut-turut $200 \mathrm{mg}$ dan $179 \mathrm{mg}$ (Scalbert \& Williamson 2000).

\section{KESIMPULAN}

Melalui penelitian ini diketahui bahwa minyak bekatul-cokelat dan ekstrak meniran layak dikembangkan sebagai minuman fungsional. Minuman emulsi yang terpilih memiliki kapasitas antioksidan, bilangan TBA, kadar protein, kadar lemak, kadar karbohidrat, kadar abu, dan kadar air berturutturut sebagai berikut: $37.68 \% ; 0.120 \mathrm{mg} \mathrm{MA} \mathrm{eq} / \mathrm{kg}$ sampel; $0.24 \%$; $0.52 \%$; $6.74 \% ; 0.15 \%$; dan $92.32 \%$.
Perbedaan konsentrasi minyak bekatul dan cokelat berpengaruh secara nyata terhadap hasil analisis $(p<0.05)$. Komponen aktif yang terdapat dalam serbuk ekstrak meniran yang diduga berperan dalam aktivitas antiproliferasi adalah flavones, quercetin, rutin, kaempferol, dan fillantin. Total fenol serbuk ekstrak meniran mencapai $92.75 \mathrm{mg} / 100 \mathrm{~g}$ dengan aktivitas antioksidan setara dengan $9.125 \mathrm{mg} / 100$ g AEAC. Total fenol minuman ekstrak meniran yang tertinggi dicapai oleh konsentrasi $70 \mathrm{ppm}$ yaitu sebesar $12.4 \mathrm{mg} / 200 \mathrm{ml}$. Aktivitas antioksidan minuman ekstrak meniran yang tertinggi dicapai oleh konsentrasi $70 \mathrm{ppm}$ yaitu setara dengan $1.31 \mathrm{mg}$ AEAC dalam $200 \mathrm{ml}$.

\section{DAFTAR PUSTAKA}

Ames BN, Shigenaga MK, \& Hagen TM. 1993. Oxidants, antioxidants, and the degenerative diseases of aging. Proceedings of the National Academy of Sciences USA, 90, 7915-7922.

Apriyantono A, Fardiaz D, Puspitasari NL, \& Budijanto S. 1989. Analisis Pangan. Pusat Antar Universitas Pangan dan Gizi IPB, Bogor.

Cai Y, Luo Q, Sun M, \& Corke H. 2004. Antioxidant activity and phenolic compounds of 112 traditional Chinese medical plant associated with anticancer. Life Sciences, 74(17), 21572184.

Damayanthi E, Kustiyah L, Kardinah, \& Roosita K. 2011. Efektivitas jus tomat dan minuman bekatul terhadap pengecilan ukuran lesi kista payudara. Indonesian Journal of Cancer $\mathrm{Na}$ tional Cancer Center, 5(1), 25-30.

Damayanthi E, Kustiyah L, Khalid M, \& Farizal H. 2010. Aktivitas antioksidan bekatul lebih tinggi daripada jus tomat dan penurunan aktivitas antioksidan serum setelah intervensi minuman kaya antioksidan. Jurnal Gizi dan Pangan, 5(3), 205-210. 
Damayanthi E, Effendi R, Kustiyah L, \& Kusumorini N. 2009. Control of Blood Glucose Level by Green Tea or Mullberry Leaf Tea on Diabetic Rats. Proceeding of International Conference Investing in Food Quality, Safety and Nutrition (hlm. 417-424), Jakarta.

Damayanthi E, Muchtadi D, Zakaria FR, Wijaya CH, Syarief H, \& Damardjati DS. 2004. Aktivitas antioksidan minyak bekatul awet dan fraksinya secara in vitro. Jurnal Teknologi dan Industri pangan, 15(1), 11-19.

Damayanthi E, Muchtadi D, Zakaria FR, Wijaya CH, Syarief $H$, \& Damardjati DS. 2003. Pengaruh derajat sosoh terhadap kandungan gizi, serat pangan dan oryzanol bekatul padi (Oryza sativa) awet. Jurnal Media Gizi \& Keluarga, 27(1), 104-114.

[Depkes] Departemen Kesehatan. 2008. Riset Kesehatan Dasar Tahun 2007. Jakarta: Departemen Kesehatan RI.

Gunawan et al. 2008. Isolasi dan identifikasi senyawa terpenoid yang aktif antibakteri pada herba meniran (Phyllanthus niruri). Jurnal kimia, 2, 31-39.

Javanmardi J, Stushnoff C, Locke E \& Vivanco JM.
2003. Antioxidant activity and total phenolic content of Iranian ocimum accessions. Journal Food Chemistry, 83, 547-550.

Kubo I, Masuda N, Xiao P, \& Haraguchi H. 2002. Antioxidant activity of deodecyl gallate. Journal of Agricultural Food Chemistry, 50, 35333539.

Mangan Y. 2005. Cara Bijak Menaklukan Kanker. AgroMedia Pustaka, Depok.

Molyneux P. 2003. The use of stable free radical diphenylpicryhydrazyl (DPPH) for estimating antioxidant activity. Journal of Science Technology, 26(2), 211-219.

Pinsirodom P, Rungchaeroen J \& Liumminful A. 2010. Quality of commercial wine vinegars evaluated on the basis of total polyphenol content and antioxidant properties. Asian Journal Food Agriculture, 3(04), 389-397.

Scalbert A\& Williamson G. 2000. Dietary intake and bioavailability of polyphenols. Journal of $\mathrm{Nu}$ trition, 130, 2073S-2085S.

Tarladgis BG, Watts BM, \& Younathan MT. 1960. A distilation method for quantitave determination of malonaldehyde in rancid food. American Meat Institute Foundation, Chicago. 